\title{
Nomen est omen - Tourist image of the Balkans
}

\author{
Melanie SMITH ${ }^{1}$, JUdit SUlYOK², ANdrás JANCSIK ${ }^{3}$, LÁsZló PUCZKÓ", \\ Kornélia KISS ${ }^{4}$, Ivett SZIVA ${ }^{4}$, Árpád Ferenc PAPP-V ÁRY ${ }^{1}$ and \\ Gábor MICHALKÓ5
}

\begin{abstract}
The regime change, the South Slavic civil war, global recession and their political, economic and social consequences had a significant impact on the tourism market of South-east Europe and the Balkan region. Many potential visitors to the region were affected by their negative associations with past events, even those that happened many years ago. The image of the Balkan region has become at times almost synonymous with conflict, turmoil and unrest. However, these perceptions may be changing and are therefore worthy of exploration. The article provides a tourism oriented analysis of the area's image as a tourism destination. In accordance with the literature, the perceptions are measured by using a customer-based approach. Internet-based social media encourages the sharing of recent tourism experiences which can confirm or change associations with destinations. This study provides a content analysis of comments from one of the most popular travel portals (TripAdvisor) including key elements of the Balkan region's image. The results of the research show theoretical implications like the importance of emotional image elements, the role of locals, or the complexity of tourism experience. From a practical point of view, the conclusions can induce long term thinking about the selected destination's branding, and motivation for further research, as well.
\end{abstract}

Keywords: Balkans, tourism, image, brand, TripAdvisor, customer-based, content analysis

\section{Introduction}

Places around the world seek to attract visitors, inhabitants and investment by dedicating significant resources for those activities. In the competitive, globalized world, it is fundamental to be different, to find the unique selling points (USP) of a certain area. In theory, this needs considerable funds and a long time for realization. However, from a practical point of view, those places that know their own values and can communicate it in a consistent way are successful in the longer term, providing a sustainable future for their inhabitants, investors and visitors. The administrative boundaries and borders often do not coincide with the perceptions of the target groups (e.g. destination in the mental map of a visitor). Acknowledging this complexity, this article seeks to map a geographical area, namely the Balkans, rather than an administrative area (like a country or a city). In the present-day world, technological advancement affects the image and perceptions of places and image is no longer a one-way communication (Govers, R. and Go, F. 2009).

\footnotetext{
${ }^{1}$ Budapest Metropolitan University. H-1148. Budapest, Nagy Lajos kir. ú. 1-9. E-mails: msmith@metropolitan.hu, lpuczko@metropolitan.hu, apappvary@metropolitan.hu

${ }^{2}$ University of Pannonia. H-8200 Veszprém, Egyetem u. 10. E-mail: judit.sulyok@gmail.com

${ }^{3}$ Budapest Business School. H-1054 Budapest, Alkotmány u. 9-11. E-mail: jancsik.andras@uni-bge.hu

${ }^{4}$ Corvinus University of Budapest. H-1093 Budapest, Fôvám tér 8. E-mails: kornelia.kiss@uni-corvinus.hu, ivett.sziva@uni-corvinus.hu

${ }^{5}$ Geographical Institute, Research Centre for Astronomy and Earth Sciences, Hungarian Academy of Sciences. H-1112 Budapest, Budaörsi út 45., Corvinus University of Budapest, Marketing and Media Institute, H-1093 Budapest, Fővám tér 8. E-mail: michalko.gabor@csfk.mta.hu
} 
Our study has a dual purpose. On the one hand, it explores the particularities of a selected area's (the Balkans) offer by analysing consumer opinions related to tourism service providers using the Balkan name in nonBalkan countries or those generating Balkan experiences. In line with current advances in tourism research, the study is based on content analysis that has become more and more popular among tourism researchers. On the other hand, the study proposes exploring the tourism-related substance of the term 'Balkan' i.e. what makes a service Balkan in the visitors' opinion, by analysing experiences related to the tourist services used in Balkan countries. Thus, the study seeks an answer to the question of whether the particularities of Balkan-related tourist services perceived as Balkan by the consumer carry any characteristic signs which can be used to develop a product with the Balkan brand name which could be sold successfully in tourism.

\section{Branding in tourism}

A successful brand is undoubtedly a powerful tool for differentiation, providing a competitive advantage (TAsci, A.D.A. et al. 2007; Boo, S. et al. 2009; ETC-UNWTO 2009). A brand has four dimensions, namely awareness, image, quality and loyalty (KonecniK, M. and GARTNER, W.C. 2007), that can be extended by value and experience (Boo, S. et al. 2009). Tourism researchers agree that image plays the main role (LeE, G. et al. 2006; KoneCNiK, M. and Gartner, W.C. 2007) in destination branding, so the image is also at the forefront of tourism researchers. Brand image (also using the terms brand identity or brand equity in the literature) has its origin in destination image (GARTNER, W.C. 2014). Besides the rational attributes, the emotional level of the brand is widely accepted (LAIтAмёкI, J.M. and Н̈̈мÄLÄINEN, T.J. 2008; ETC-UNWTO 2009; Moilanen, T. and Rainisto, S. 2009; SARAniemi, S. 2010; Usakli, A. and Baloglu, S. 2011), extended by personality characteristics (UsAKli, A. and Baloglu, S. 2011) which means the human dimension enabling a better involvement of the travellers (Kumar, V. and NAJAK, V.K. 2014). The brand has furthermore a strong connection with the travellers' lifestyle and ideal self-congruence (NAM, J. et al. 2011; Usakli, A. and Baloglu, S. 2011; Barnes, S.J. et al. 2014). The brand personality is strongly linked to the residents and hosts of the destination, i.e. residents' identity influences their attitudes towards tourism/tourists (WANG, S. and $\mathrm{XU}_{\mathrm{U}}, \mathrm{H}$. 2015), and locals can also be involved in advocacy activities (PAlmer, A. et al. 2013).

In the case of the Balkans, the question is whether the very wide array of different countries could come together under the umbrella of the term 'Balkan'? The national stereotypes, which are often unpopular with the locals themselves, even if they are positive (ETC-UNWTO 2009) - can be a limitation in this process. Taking a look at some 'success stories', like European Quartet (Visegrad 4 countries), the Baltic countries, Europe's marketing overseas or US branding out of the USA, we can see a strong emphasis on promotion rather than on - the very complex - branding. This takes us to the brand architecture. Meanwhile, sub-national branding is more effective (ETC-UNWTO 2009) (e.g. Andalusia in Spain, Provence in France or Toscana in Italy), supra-national brands can have an impact on visitor flows if the countries are quite similar and small, or when they are relatively unknown which can be the case in the Balkans.

Tourism service providers and marketing organizations of various tourist destinations have a great propensity for using attractive-sounding geographical names to emphasize the regional relevance and/or particularities of the various offers (KozmA, G. and Ashworth, G. 1993; Kavaratzis, M. and Ashworth, G. 2005). The geographical name can even represent the service itself, i.e. it becomes a symbiotic brand (Kozma, G. 1995; Papp-VÁry, A. 2013; Kavaratzis, M. et al. 2015). Geographically relevant brands gain more significance with distance, which means they orientate the consumers from 
more distant places (ETC-UNWTO 2009). Even if 'places' are at the forefront of branding today, the available literature mainly focuses on administrative areas which raises the challenge of which administrative areas destinations (like the Balkan countries) belong. In the case of the Balkans, the situation is quite negative (Photo 1 ).

While the geographical associations with other so-called regional brand names which are quite well known in European tourism (such as Alpine wellness, Carpatair, Mediterranean Hotels, Nordic wellbeing, Scandinavian Airlines) trigger positive or at most, neutral conceptual associations.

Conceptual associations related to a tourist destination affect its competitiveness (Qu, H. et al. 2011; Pike, S. and PAGE, S. 2014). In spite of the fact that the geographical names which embody tourist destinations can create negative images and generate negative conceptual associations, astute product development and marketing communication could shape that fame or notoriety into a competitive edge (TAsci, A.D.A. et al. 2007; CAKмаK, E. and IsAaC, R. 2012). Glasgow, formerly an embodiment of Scottish coal mining, acquired the title 'European Cultural Capital' (1990) and Essen, the German centre of heavy industry and a citadel of the Ruhr region, was declared part of the UNESCO World Heritage (2001). These events helped both take major steps towards leveraging their popularity in tourism (RÁtz, T. 2006).

These examples prove that inherent negative associations can be converted into positive ones by transforming the geographical names into brand names used in tourism. This is largely facilitated by the fact that tourism is one of the economic sectors associated with the highest number and most favourable pieces of news (WTO 2002).

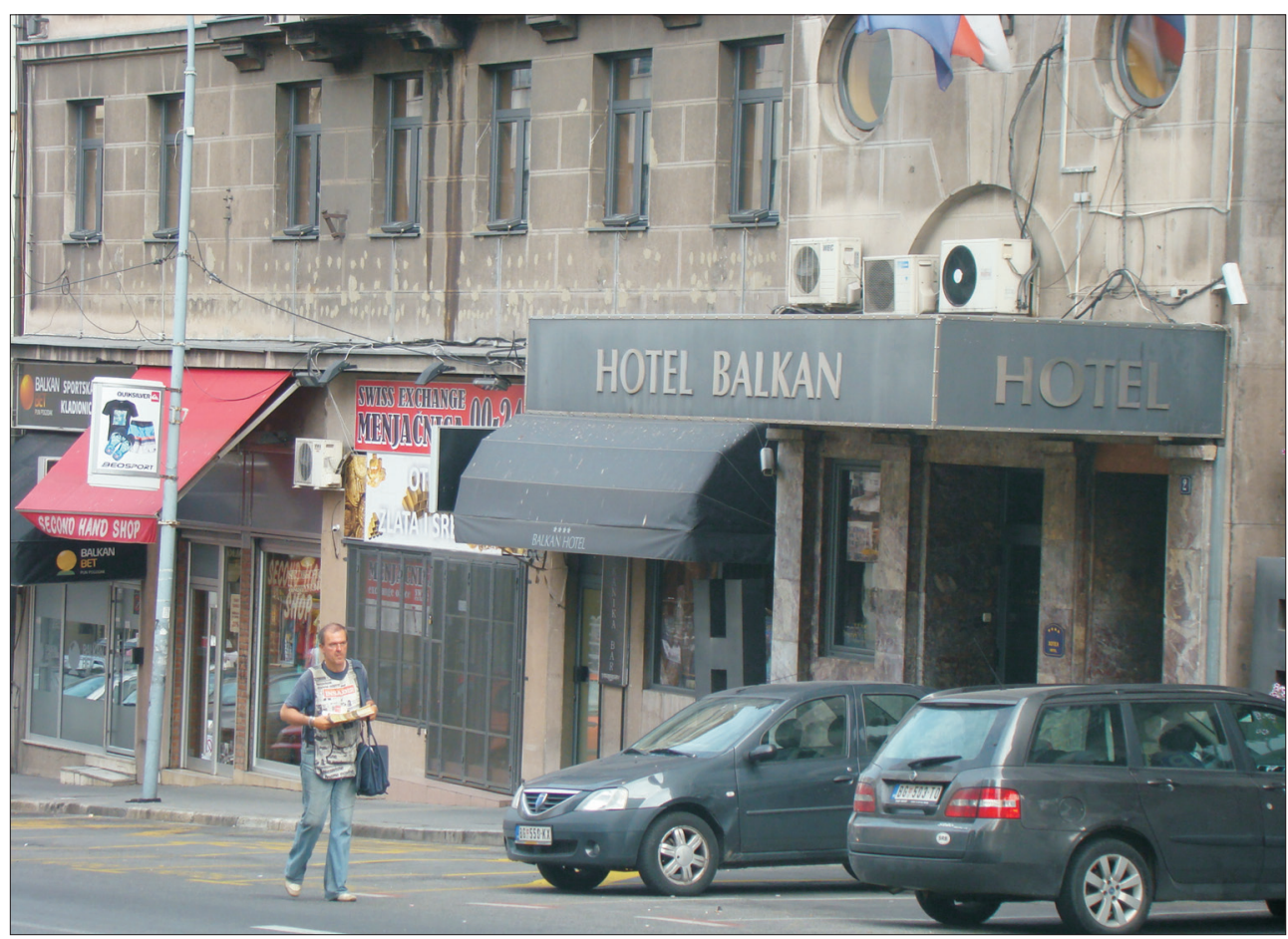

Photo 1. Hotel Balkan in Belgrade: where tourists can be positively disappointed too (Photo by MicHALKó, G.) 


\section{The 'power' of the travellers}

Although acknowledging its complexity (GARCíA, J.A. et al. 2012), many brand studies focus on a narrow aspect of branding (PIKE, S. 2002). Reflecting the 'power of the travellers', consumer (or customer)-based analysis (e.g. Konecnik, M. and Gartner, W.C. 2007; TAsci, A.D.A. et al. 2007; Boo, S. et al. 2009) are mostly used. Recently, stakeholders' dimensions (Marzano, G. and Scott, N. 2009; dos Santos, E.R.M. 2014) also came into focus, including host communities (Dos Santos, E.R.M. 2014) or the analysis of official communication messages (e.g. promotional brochures) (BRITO, P.Q. and Pratas, J. 2015). The stakeholder perspective of branding considers the actors as decision-makers, accepting that the destination brand is the 'outcome of the achievement of unity and collaboration among the stakeholders' (Marzano, G. and ScotT, N. $2009,249)$. At the same time, there are valuable case studies focusing on a mixture of stakeholders (GARCíA, J.A. et al. 2012) or a special segment like attendees of conferences (LEE, J.S. and BACK, K.J. 2010). Although the intermediary stakeholders (marketing, media) play a fundamental role in tourism, the branding literature gives less attention to them (e.g. among the reviewed studies by PIKE, S. [2002, 2009] there were no media targeted).

On the other hand, opinions of tourists who have previously visited the desired destination play a significant role in the decisions made by potential tourists, which was known as word of mouth in the old days $(\mathrm{OH}, \mathrm{H}$. 1999; KozAK, M. 2010; Martin, W. and LuEg, J. 2013) and 'word of mouse' or similar today. (Table 1) The current reviews and comments posted on various internet forums can influence demand behaviour (JACOBSEN, J.K.S. and MunAR, A.M. 2012; Munar, A.M. and JacobSEn, J.K.S. 2014; LADHARI, R. and MichaUd, M. 2015).

Controlling word of mouth is extremely difficult, for example, in the case of hotels, it is a common practice that only 'real' guests who booked and stayed can share their views. However, the online reviews are available to the service providers who can use them to shape their offers (Chaves, M. et al. 2012; Mauri, A. and Minazzi, R. 2013; Luo, Q. and ZHong, D. 2015). As it is the primary interest of tourist service providers to have up-to-date information about their customers' satisfaction, they try to follow up on the online reviews they receive, which are also factored into the shaping of their brand (Grewal, R. et al. 2003; Vermeulen, I. and Seegers, D. 2009; Torres, E. et al. 2014).

Among the available portals for providing feedback from travellers, TripAdvisor is the leading source. With over 630 million reviews and opinions covering the world's largest selection of travel listings worldwide - covering approximately 7.5 million accommodations, airlines, attractions, and restaurants - TripAdvisor provides travellers with the wisdom of the crowds to help them de-

Table 1. Which of the following information sources do you think are most important when you make a decision about your travel plans?*

\begin{tabular}{l|c}
\hline \multicolumn{1}{c|}{ Information source } & EU 28, \% \\
\hline Recommendations of friends, colleagues or relatives & 51 \\
Websites collecting and presenting comments, reviews and ratings from travellers & 34 \\
Personal experience & 33 \\
Websites run by service provider or by destination & 17 \\
Counters of travel agencies and tourism offices & 13 \\
Social media pages (for accommodation, restaurants, transport companies, etc.) & 12 \\
Newspaper, radio, TV & 11 \\
Paid for guidebooks and magazines & 9 \\
Other & 3 \\
\hline
\end{tabular}

${ }^{*}$ Maximum 3 answers were accepted. Source: Flash Eurobarometer 432: Preferences of Europeans towards tourism. Own editing. 
cide where to stay, how to fly, what to do and where to eat. TripAdvisor-branded sites are available in 49 markets, and are home to the world's largest travel community of 455 million average monthly unique visitors ${ }^{6}$.

From the research point of view, TripAdvisor is used in most of the tourismrelated case studies and academic articles dealing with content analysis. Over 100 papers used it as source for research since 2016 (GAL-Tzur, A. et al. 2018). In the case of hotels, other portals (e.g. booking.com or Airbnb) are also used regularly by tourism researchers. When talking about a destination such as the Balkan area, the selection of the TripAdvisor data is appropriate to map the image elements or the destination (Table 2.)

Taking a closer look at the selected social media-oriented and content analysis methodbased tourism research, the usefulness is evident both from the theoretical and from the practical point of view. The social media content (including review sites) is an appropriate tool for tracking image elements (Govers, R. and Go, F. 2009; Kladou, S. and Mavragani, E. 2015; Marine-Roig, E. and Anton Clavé, S. 2015), and also a very valuable input for identifying brand equity (Marine-Roig, E. and Anton Clavé, S. 2015; Malenkina, N. and Ivanov, S. 2018; Thanh, T.V. and Kirova, V. 2018). This kind of information is in line with tourism knowledge like tourism image main dimensions (cognitive, affective, conative) (Kladou, S. and Mavragani, E. 2015), the AIDA model (Malenkina, N. and Ivanov, S. 2018) or the experience model (ThanH, T.V. and Kirova, V. 2018). Simply by just being there on a review portal can help potential visitors to reduce uncertainty (RAGUSEO, E. et al. 2017). Tracking visitors' feedback can support understanding their needs, expectations and behaviour (GANzaroli, A. et al. 2017; Rodrigues, H. et al. 2017; GaL-Tzur, A. et al. 2018; Malenkina, N. and Ivanov, S. 2018), and also the effects of tourism trends can be monitored (MARINE-Roig, E. and Anton Clavé, S. 2015).

\footnotetext{
${ }^{6}$ Information from TripAdvisor (www.tripadvisor.com, retrieved in April 2018).
}

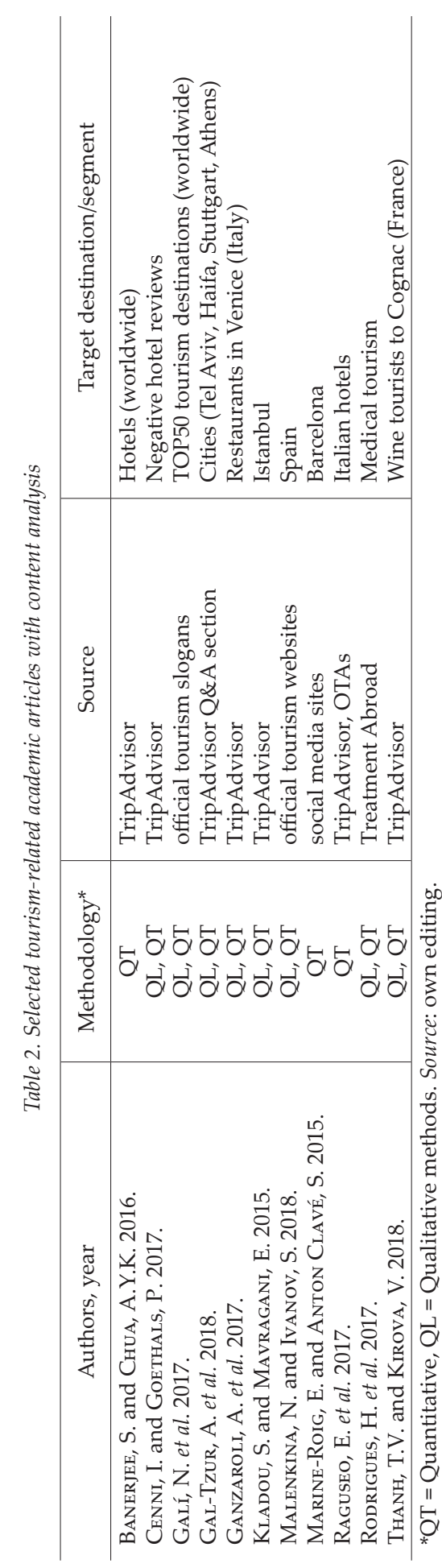


Another important aspect is that content analysis is appropriate for mapping differences between segments (BANERJEE, S. and ChuA, A.Y.K. 2016; Rodrigues, H. et al. 2017), and the geographical location can also influence the ratings (BANERJEE, S. and Chus, A.Y.K. 2016). From the practical point of view, the results can support future developments and marketing communication (Kladou, S. and Mavragani, E. 2015; Banerjee, S. and Chua, A.Y.K. 2016; MarineRoig, E. and Anton Clavé, S. 2015; GalTzur, A. et al. 2018), or just simply identify need for intervention (e.g. transportation).

\section{The Balkans as a destination}

Balkan Airlines which operated from 1947 to 2002 can now be seen as one of the success stories in terms of using the Balkans as a geographical name in tourism (ERDósI, F. 2007). The Bulgarian national airline flew the Balkans name to fifty countries on four continents for five decades, contributing (consciously or unconsciously) to associations with the term Balkans in the context of tourism. At the same time, the Balkan region, which was named after the Balkan Mountains located in Bulgaria and has often been associated with Southeast Europe (Kocsis, K. 2007), encouraged other tourism businesses to offer their services under this well-known geographical name. One prominent example is the Sofia Hotel Balkan located in the heart of the Bulgarian capital, currently operated by the world-famous Sheraton chain of luxury hotels. But just as the geographical interpretation of the Balkans extends well beyond the boundaries of Bulgaria (PAP, N. 2013; PAP, N. and REMÉNYI, P. 2017), travellers can see tourism services offered under the Balkans name everywhere in the world.

However, due to some of the more negative associations which developed during periods of conflict and war, the use of the geographical name Balkans as a tourism-oriented brand in the future requires a broader examination of the term and its inherent associations. TAMMINEN, T. (2004) suggests that the term 'Balkanization' alludes to instability and conflict, whereas 'Europeanization' is understood as the adoption of 'Western norms' and 'European' values and practices. Matanov, A. et al. (2013) describe how the collapse of Yugoslavia in the early 1990s precipitated the worst armed conflict in Europe since WWII with war activities spanning ten years, and Akova, S. and Demirkiran, C. (2013) refer to a multitude of historical conflicts and civil wars, as well as an unstable environment. O' BRENNAN, J. (2014, 239) states that the Western Balkans in particular still remains , a region of great fragility, defined by inter-ethnic contestation for territory and power and „mutually antagonistic nationalisms". Rightly or wrongly, therefore, the image of the region has often become synonymous with conflict. As stated by Vitic, A. and Ringer, G. $(2008,128)$,perhaps the most pervasive - and disruptive to tourism's revival in the Balkan states - are the dated, and often inaccurate, misperceptions and images of the civil wars and ethnic barriers that prevailed throughout the 1980s and early 1990s, yet still define the region for many international visitors and tour operators". Whether this is still the case is a subject worthy of further exploration.

The term Balkans and the content and quality of the services provided by tourism businesses using it are in close relationship, and other associations related to the Balkans (external ones i.e. not those generated by tourism) inevitably shape tourists' attitudes to the Balkan name. However, it should be noted here that it is deeply contested as to which countries form part of the Balkans, and the authors acknowledge that there are huge variations within the countries which are said to be located in the Balkans. On the other hand, tourists' knowledge of the history, geography and politics of the region may be sketchy at best, but they may still have some associations with the Balkans as a concept, region or even destination.

The Balkans can be seen as a geographical name which is more or less known as a destination for the average person and is likely 
to evoke various tourism-related references (Áвrahám, B. 2007; Seben, G. 2007). If the Balkans as a geographical name became a successful tourism brand, it could facilitate not only the socio-economic development of the region and its geopolitical stability, but also the process of the European Union's expansion and achievement of its security policy objectives (AnAstasakis, O. 2000). This could be enhanced by the fact that the Balkans has become a relatively positive brand name both in fashion and music; for example, bags and wallets made of recycled bicycle tyres are sold by a Hungarian-Swiss company under the brand name BalkanTango, while The Balkan Fanatik music band enjoys international recognition, too.

The term Balkans has taken on geopolitical dimensions in addition to locational ones. The Balkan Peninsula which provides the physical geographical boundaries was named after the Balkan Mountains located in Bulgaria (SzÉKely, A. 1970). The physical delimitation of the Balkan Peninsula itself is a topic of professional debates; literature reports 17 different boundaries, while researchers agree that the Danube-Sava-Kupa rivers create a fairly clear line (PAP, N. 2013). For centuries, knowing and understanding the Balkans have been the objective of travellers, thinkers and researchers from various fields of science (Hajdú, Z. 2003; BraceWell, W. and Drace-Francis, A. 2009; Kőszegi, M. 2010; SAnguin, A. 2011; NAGY, M. 2012).

As mentioned, the Balkans is a geographical name with negative connotations, so as a result, associations with and perceptions of the region also incorporate elements which represent the darker side of life (CARTER, F.W. and Norris, H.T. 1996; REDEPENNING, M. 2002; Garde, P. 2007; Császár, M.Zs. and PAP, N. 2011). In connection with its role in the history of Europe, in particular on account of the wars and delayed development as a result of them, the Balkans is a geographical term which does not tend to reflect many positive aspects of life (Newman, B. 1945; Kaplan, R. 1994; Arday, L. 2002; Bideleux, R. and JefFries, I. 2007). The images which characterized the Balkans at the turn of the $19^{\text {th }} / 20^{\text {th }}$ century (e.g. "sick man of Europe", "powder keg of Europe") are still present in public opinion related to this region (Rutar, S. 2004; Hajdú, Z. 2007; Petrovic, M. 2008). The late modern and postmodern eras in the Balkan region were characterized by destructive nationalism, ethnic conflicts, wars and ongoing instability (BоттLIк, Zs. 2009; Clemens, V. 2010; PAP, N. 2013; Iov, C.A. and Ivan, A.L. 2014; JovanovićA, S. et al. 2015; Kadiu, F. 2015).

The negative connotations of the Balkans are magnified by the term balkanization, which is widespread in British-American social scientific literature as a description of the fragmentation and division of a community or a nation (Ellis, M. and Wright, R. 1998). From the branding point of view, the Balkans name's negative connotations can be a paradox when emphasizing the positive effect of branding on place identity (ETC-UNWTO 2009), on diminishing negative effects of crisis (ETC-UNWTO 2009; Moilanen, T. and Rainisto, S. 2009) or on transmitting value (MoILANEN, T. and Rainisto, S. 2009; Saraniemi, S. 2010).

\section{Methodology}

After considering some acknowledged methods for tourism destination image research, including netnography, big data and content analysis, for this analysis content analysis was chosen. This meant the systematic evaluation of content, which was the texts written by tourists in this case. The research process follows the traditional method of content analysis, namely information-processing where the preselected texts are transformed through systematic categorization into data that can be analysed further (CAMPRUBí, R. and Coromina, L. 2016).

One of the key stages in the study is identifying the content and meanings inherent in the word Balkans/Balkan. Knowing which elements are described in the travel experiences of visitors to Balkan countries as being typically Balkan, could be used to change the image of the Balkans which people have formed. 
For this, we used the database of one of the most popular travel portals, TripAdvisor. TripAdvisor is a platform for tourists to rate or review destinations and services used by tourists, to create a place of dialogue or forum for the stakeholders and interested parties. It has excellent search capabilities, but also involves many factors which limit the validity of scientific results (AyEH, J. et al. 2013). Our analysis was performed based on a database created from information posted on TripAdvisor and downloaded before March $7^{\text {th }} 2014$.

To collect the phrases including the word 'Balkans/Balkan' from descriptions of tourist experiences, a relatively simple Excel database was created from the set of results using the search terms. The basic sample was created from 3,860 reviews which included the word 'Balkans/Balkan' either in the name of the reviewed facility, the brief title of the review or the body of the review itself (Table 3).

As our study focuses on the international dimension of the tourism-related aspects of the term 'Balkan', we restricted our analysis to reviews of citizens from countries lying outside the studied area (i.e. clearly non-Balkan), while reviews of posts with unidentified nationality were excluded from start. The database obtained was suitable for grouping reviews by country for the purposes of our analysis, breaking down the experiences related to countries lying in the studied area (1,861 reviews) and those outside (1,999 reviews). In addition to this essential categorization, we used a database suitable for filtering the following information:

- Exact name of the reviewed place;

- Type of the reviewed place (accommodation, catering, tourist attraction);
- Brief informative title of the review.

Although 22 per cent of the reviews were initially posted on TripAdvisor in another language than English, the various longer or shorter reviews and additional pieces of information were available in English thanks to the English language function of the portal. We searched the terms Balkan/Balkans with British spelling, making sure that information would not be left out of our database because of any misspelling by the reviewers (e.g. missing letters).

Using the database compiled above, we conducted a content analysis. As part of this, we focused on phrases which included the terms Balkan/Balkans in the reviews, as well as the words directly associated with them and grouped them according to the content. We applied two approaches in the analysis. Firstly, we analysed the Balkan particularities of tourist services available in countries outside the studied area. Secondly, we dissected the elements of what 'Balkan' means in the experiences which took place in Balkan countries (Figure 1).

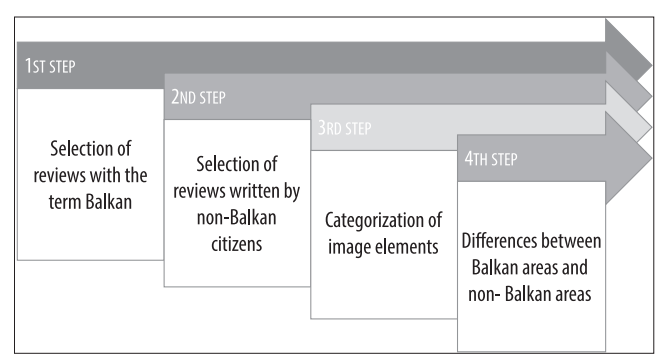

Fig.1. Data analysis process - main research steps. Source: Authors' research

Table 3. Study sample with the number of opinions in units

\begin{tabular}{|c|c|c|c|c|}
\hline \multirow{2}{*}{$\begin{array}{l}\text { Number of reviews related } \\
\text { to the facility located }\end{array}$} & \multicolumn{3}{|c|}{ The word 'Balkan' in the } & \multirow[b]{2}{*}{ Together } \\
\hline & $\begin{array}{c}\text { name of } \\
\text { the facility }\end{array}$ & $\begin{array}{l}\text { title of the review } \\
\text { about the facility }\end{array}$ & $\begin{array}{l}\text { body of the review } \\
\text { about the facility }\end{array}$ & \\
\hline in the Balkans & 566 & 113 & 1,182 & 1,861 \\
\hline outside the Balkans & 904 & 162 & 933 & 1,999 \\
\hline Total reviews & 1,470 & 275 & 2,115 & 3,860 \\
\hline
\end{tabular}

Source: Own research. 


\section{Results}

\section{Quantitative results}

In line with the consulted literature, the database enabled some quantitative analysis. The geographical location of the facility (in the Balkan countries or outside) has an effect of the general evaluation: the average rating for the facilities in the Balkan countries is 3.90 (standard deviation: 1.218 ), and 4.05 (standard deviation 1.119) for the ones outside of the region.

The reviewer place of origin also influences the perceptions that can be traced in the general evaluation. Those reviewers who live in the Balkan area, are more positive (average rating of 4.18 with standard deviation of 1.034) than non-Balkan people (average rating of 3.95 with standard deviation of 1.185). Among the source markets with at least 100 comments, Russians (4.46), Spanish (4.43), Canadian (4.25) and US (4.24) visitors were the most satisfied, whereas the most 'critical' were the reviewers from England (with an average evaluation of 2.86).

According to the facility type, there are also some important outcomes. The attractions showed the best performance (in this case, the std. deviation is the lowest, as well). At the same time, accommodation - especially hotels had the weakest performance, which definitely need some developments in the future (Table 4).

Table 4. Average rating by facility type

\begin{tabular}{l|c|c}
\hline \multicolumn{1}{c|}{ Facility type } & Mean & $\begin{array}{c}\text { Standard } \\
\text { deviation }\end{array}$ \\
\hline Attraction & 4.58 & 0.722 \\
B\&B / Inn & 3.92 & 1.275 \\
Hotel & 3.55 & 1.285 \\
Restaurant & 4.19 & 1.012 \\
Speciality Lodging & 4.09 & 1.385 \\
Total & 3.97 & 1.178 \\
\hline
\end{tabular}

Source: Own research.

\section{Services with the word Balkan in their names}

The database of 3,860 elements processed as part of our study included 1,470 reviews where the word Balkans appeared in the name of the reviewed service. We noticed the word Balkan was used most often in reviews related to names of restaurants (854 reviews) and hotels (544 reviews). Most reviews (904 reviews) commented on service providers located outside the studied Balkan countries.

We identified 22 non-Balkan countries whose tourist services were referenced in reviews with the word Balkan in the title. Clearly experiences perceived as being Balkan can be acquired also when using services of tourism businesses in non-Balkan countries, and this may influence global perceptions of the Balkan region. However, geographical misunderstandings are not uncommon. For example, it transpires from the reviews that in some cases the Balkan atmosphere is associated with the Mediterranean region and the Balkan cuisine with the Turkish one. This data shows that from the image elements of the Balkan, the gastronomy has the strongest appeal and potential for 'export' (Table 5).

\section{The 'Balkan' element in the tourism experience}

From the qualitative point of view, in the tourist opinions on experiences in Balkan countries shared on the TripAdvisor travel portal, the terms Balkan/Balkans in the review body can be grouped into five categories based on the main themes of their content (1,182 reviews). Geographical location (180 reviews), cuisine (136 reviews), travel (626 reviews), culture (183 reviews), and atmosphere (57 reviews). Although the themes outlined were sometimes overlapping in the bodies of the various reviews, they were limited based on the keyword or main theme of the review (Figure 2).

Tourists visiting the Balkans often localize their experiences using the word Balkans instead of the geographical name of the country, region, city or territory of their destination. Identifying a destination or a service provider as being Balkan during a trip to a Balkan country means that the tourist has a certain understanding of the geographical scope of the Balkans (i.e. a mental map) and is certain about being in the Balkans. 
Table 5. Use of the word 'Balkan' in titles of reviews on the tourist restaurants of countries lying outside the Balkans

\begin{tabular}{l|c|l|l}
\hline \multicolumn{1}{c|}{ Country } & $\begin{array}{c}\text { Number } \\
\text { of reviews }\end{array}$ & \multicolumn{1}{|c|}{$\begin{array}{c}\text { Names in the description of the } \\
\text { service reviewed }\end{array}$} & $\begin{array}{l}\text { Occurrences of the word 'Balkan' } \\
\text { in the review titles }\end{array}$ \\
\hline Denmark & 4 & $\begin{array}{l}\text { Herzegovina } \\
\text { Ankara }\end{array}$ & $\begin{array}{l}\text { Balkan atmosphere } \\
\text { Balkan food }\end{array}$ \\
\hline South Korea & 1 & Zelen & Balkan food \\
\hline Israel & 4 & $\begin{array}{l}\text { Montenegro } \\
\text { Nanuchka } \\
\text { Arnold }\end{array}$ & $\begin{array}{l}\text { Balkan food } \\
\text { Balkanian (sic) touch }\end{array}$ \\
\hline Poland & 1 & Bukara & Balkan cuisine \\
\hline Hungary & 2 & $\begin{array}{l}\text { Paros } \\
\text { Banja Luka } \\
\text { Maly Belgrad } \\
\text { Bulgaria Magica } \\
\text { Balbinka }\end{array}$ & $\begin{array}{l}\text { Balkan night } \\
\text { Balkan cuisine } \\
\text { Balkan food } \\
\text { Balkan and Turkish cuisine }\end{array}$ \\
\hline Malta & 1 & Montenegro & $\begin{array}{l}\text { Balkan food } \\
\text { Taste of the Balkans }\end{array}$ \\
\hline
\end{tabular}

Source: Authors' data collection based on TripAdvisor.

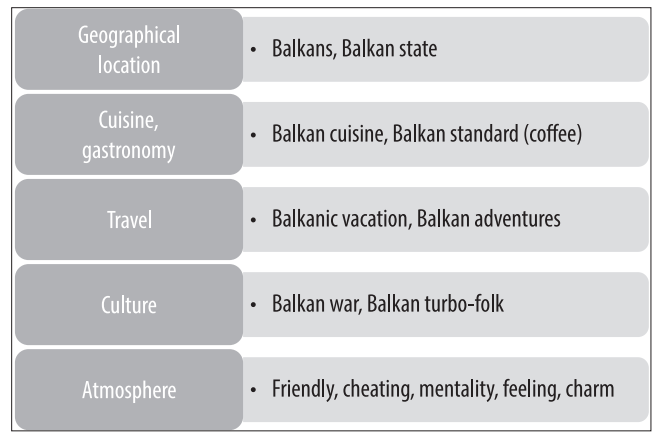

Fig. 2. Dimensions of the Balkan image with some examples. Source: Authors' data collection based on TripAdvisor

For example, a Dutch tourist who visited Albania praises the hotel where he stayed by saying: "This is one of the best hotels in the Balkans."

Reviews often identify the geographical location of a country, stating that it is part of the Balkans, as did a British tourist visiting Montenegro: "Montenegro is a new Balkan state born out of the wars of the 90s."

Dedicating a separate category to travel in our discussion was necessary because the word Balkan tends to emphasise the importance of the Balkans as a region, and not only of the individual countries in which the tourists find themselves.
For example, a Swedish tourist who spent the holidays in Montenegro reported his experience at the given destination as being specifically Balkanic (sic!) rather than Montenegrin. He felt that the observations made during the vacation apply to the Balkans as a whole and can be replicated in any Balkan country: "This is the perfect place for an excellent Balkanic vacation."

When an Israeli tourist who visited Slovenia recommended a hotel in Ljubljana, he presented the travel as a Balkan trip: "If you're beginning your Balkan adventures in Ljubljana and want to start in confidence, may I recommend the Austria Trend Hotel?"

When describing the gastronomy, tourists tend to label the offer of a given catering facility as being typically Balkan. The meals most frequently mentioned include grilled meat (mutton), fresh vegetables, enticing sweets, tasty wines and home-made liqueurs. The specific offers are hallmarked by cevapcici, kebab, lepinja, rakia and shopska salad.

Reviews from tourists who mention the Balkan cuisine are generally appreciative, as seen in the post of a Polish tourist who visited Serbia: "After a whole day of visiting Belgrade, it is a perfect place to enjoy delicious Balkan cuisine."

A British guest in Bosnia-Herzegovina complained about the quality of coffee served there, but also implies that standards of Balkan cuisine tend to be usually high: "The only let down for me has been the coffee, which on at least 2 occasions is not up to Balkan standard." 
The reviews described culture as a specific Balkan attraction with a regional dimension that crosses borders. However, the legacy of wars is mentioned frequently.

For example, a British tourist visiting Mostar in Bosnia-Herzegovina to see the rebuilt Old Bridge stated that: "We felt making the effort to visit Mostar was well worth it, after watching its demise in the Balkan War."

Music is another element of culture which is described often and usually positively.

A German tourist reporting on his visit to Serbia mentions a specific musical trend, turbo folk, a popular music rooted in folk music: "The evening started with international music with a Spanish theme and ended with Balkan turbo-folk."

Atmosphere proves to be a more ambivalent category, with both positive and negative comments. The heritage environment is viewed positively, whereas the infrastructure is frequently not. Balkan people are seen as friendly and hospitable by many, but service levels and attitudes are also viewed less favourably. Cheating and scams are also mentioned on several occasions.

If a tourist feels he does not get the quality of service he paid for, he feels defrauded and sometimes rates the experience 'Balkan', as an Indian customer visiting Croatia did: "Middle-class hotel with Balkan mentality, at Monaco prices. No real service. [...] Huge disappointment, first (and last) time I was in Croatia, cheat other people from now on instead of us."

However, a German citizen's review about Montenegro implies that Balkan 'atmosphere' can be positive: "Budva is definitely a nice party city, Balkan feeling is in the air."

\section{Summary of results}

The brief analysis and examples above show that the meaning behind the Balkan attribute can be understood relatively easily in the case of tourists who shared their experiences of the Balkan countries through the TripAdvisor travel portal. The existence of the 'Balkan' in travellers' experiences (demand side) could be integrated into the stakeholders' view, tak- ing advantage of perceptions already measurable. The geographical context of the selected area can be tracked in the database involved in the research. Travel experiences were reported as typically Balkan probably because the visitors could personally engage in the various elements of the image of the Balkans they had (fixed) in their minds. From the main image elements arising in the analysis (based on the categorization of the texts' content), the gastronomy has the best potential in showcasing 'Balkan experience' outside of the region itself. Gastronomy - namely restaurants - are also in the forefront of image shaping outside of the researched area, as these are the most common facilities, and those with the most positive image.

Evaluating the results, it seems that the term Balkan can be construed as an umbrella concept of two experiences which occasionally overlap: the first is meant to express the simplified geographical identification of experiences from Balkan countries on the experiencing parties' mental map; the second (partially related to the first one) is a rating with an axiological substance, too, which is positive in some cases, contrary to common myth that all associations with the Balkans tend to be negative. From the residents' point of view, the Balkans has also an important role in the local identity, as reviewers from the areas tend to be more positive, proud of their values that is reflected also in the general scores.

The fact that a tourist rates something as Balkan in a TripAdvisor post is an expression of the expected experience in most cases. This means that it can be construed as a manifestation of an experience in a Balkan country corresponding to the pre-existing expectations (this can be positive, too, for example when tasting Balkan cuisine, or negative, for example regarding the facilities or cleanliness in a Balkan hotel). But there are cases where the experiences of the tourist acquire a Balkan attribute not in the light of expectations, but experiences i.e. the negative ideas about the region in their minds are connected with a case experienced in a heightened state of emotion (e.g. being cheated or being the 
victim of rudeness). Although being a crucial element for tourism mobility, among the elements of the tourism value chain, accommodation has the weakest performance.

The tourist dimension of 'Balkan' was expressed best perhaps by a British tourist visiting Romania: "This is a Balkan country and if you don't know what this means from a cultural point of view you are missing the charm of visiting foreign places."

The term charm encapsulates well the complex nature of Balkan experiences. It implies that visiting a Balkan country will be enriched with an unparalleled experience of life and impressions which, as our study confirms, are nourished by becoming aware of the geographical location, the regional character of the territory which transcends the country boundaries, the cuisine, a tourist offer full of challenges, as well as joy, the cultural traditions rooted deeply in history, but also conflict, and the atmosphere. Perhaps unexpectedly, experiences rated as being Balkan appear mostly in a context where satisfaction is the dominant feeling, therefore, the term Balkan does not necessarily carry unfavourable connotations.

\section{Conclusions}

This study in no way expresses the complexity of interpretations which abound in relation to the Balkans as a geographical or political entity. However, the results of the analysis show important theoretical and practical implications. From the theoretical point of view, the selected methodology in line with recent academic literature (e.g. Kladou, S. and Mavragani, E. 2015; MarineRoig, E. and Anton Clavé, S. 2015) enables the measurement of a realistic image dimension of the selected destination. It is recognized that image creation and brand building are exceptionally complex in tourism and can take many years, if not decades.

Revisiting the tourism branding literature, regional branding is even less common than national or city level branding. However, the study does underpin the relevance of geographical dimensions of branding, as the term 'Balkan' is still used quite widely by international visitors to the region, regardless of the country that they are visiting. Thus, the results of the content analysis can support the identification of the area's brand equity (Marine-Roig, E. and Anton Clavé, S. 2015; Malenkina, N. and Ivanov, S. 2018; Thanh, T.V. and Kirova, V. 2018). Regarding the image elements, the study underpins the importance of emotional dimensions, furthermore the need for involvement of the residents (who are the 'service providers' meeting the visitors) shaping the environment and communicating through their behaviour (WANG, S. and $\mathrm{X}_{\mathrm{U}}, \mathrm{H}$. 2015). In the case of the researched area, we can also conclude that locals have a strong identity that can be seen as a positive element (reflected in the scores given). The study, also in line with the reviewed literature (BANERJEE, S. and ChuA, A.Y.K. 2016; Rodrigues, H. et al. 2017) underpins the difference between certain segments (e.g. according to reviewers' place of residence) in the perceptions of the Balkans.

From a practical point of view, the paper acknowledges the rich national variations which clearly exist in terms of development levels, resources, facilities, services or attractions in tourism. However, accommodation clearly has the weakest performance, meanwhile attractions and restaurants can be a good starting point for communicating 'Balkan' experience. Also from the demand point of view, the analysis underpins the difference of segments, the role of residence (country), and thus, socio-cultural background in perception building. In this regard, the research can be seen as the starting point for new discussions about the Balkans as a tourist region, especially for international tourists, many of whom will be too young to personally remember many of the past conflicts in the region. Opinions about tourist services using the geographical name Balkans can shape the region's tourism-related image not only by transfers associated with the given location or other service providers (e.g. 
media, internet, word of mouth marketing), but also because of the general economic, political and cultural conceptual associations related to the Balkans. The use of the term 'Balkan' in reviews is still somewhat mixed in terms of positive and negative connotations, but the predominance of positive comments is perhaps a hopeful sign of changing attitudes and perceptions to this exciting but as yet, still relatively under-visited region.

The results of the research can provide valuable input for future developments and marketing communication (KLADOU, S. and Mavragani, E. 2015; Marine-Roig, E. and Anton Clavé, S. 2015; Banerjee, S. and ChuA, A.Y.K. 2016; Gal-Tzur, A. et al. 2018) of the Balkan region as a tourism destination. The negative comments in areas that need intervention can help destination managers and service providers in meeting expectations of travellers and in providing good quality service and experiences.

\section{REFERENCES}

ÁвrAна́м, B. 2007. A Balkán képe a 19-20. századi magyar geopolitikai és tudományos gondolkodásban (The image of the Balkans in the Hungarian geopolitical and scientific thinking of the $19^{\text {th }}-20^{\text {th }}$ century). Regio 18. (2): 47-78.

Akova, S. and Demirkiran, C. 2013. Regarding the Culture of Multi-Ethnicity and Cohabitation in the Western Balkans. Human 3. (2): 6-16.

Anastasakis, O. 2000. A balkáni régió európai integrációja (European integration of the Balkan region). Pro Minoritate, Autumn-Winter, 44-54.

Arday, L. 2002. After Yugoslavia: Problems and perspectives in the Balkans. Foreign Policy Review 1. 162-192.

Ayeh, J., Au, N. and Law, R. 2013. Do we believe in TripAdvisor? Examining credibility perceptions and online travellers' attitude towards using user-generated content. Journal of Travel Research 52. (4): 437-452.

Banerjee, S. and ChuA, A.Y.K. 2016. In search of patterns among travellers' hotel ratings in TripAdvisor. Tourism Management 53. 125-131.

Barnes, S.J., Mattsson, J. and Sorensen, F. 2014. Destination brand experience and visitor behaviour: Testing a scale in the tourism context. Annals of Tourism Research 48. 121-139.

Bideleux, R. and Jefrries, I. 2007. A History of Eastern Europe. Crisis and Change. London, Routledge.
Boo, S., Busser, J. and Baloglu, S. 2009. A model of customer-based brand equity and application for multiple destinations. Tourism Management 30. 219-231.

Bracewell, W. and Drace-Francis, A. eds. 2009. Balkan Departures: Travel Writing from Southeastern Europe. Oxford, Berghahn Books.

Brito, P.Q. and Pratas, J. 2015. Tourism brochures: Linking message, strategies, tactics and destination brand attributes. Tourism Management 48. 123-138.

CакмAK, E. and IsAaC, R. 2012. What destination marketers can learn from their visitors' blogs: an image analysis of Bethlehem, Palestine. Journal of Destination Marketing \& Management 1-2. 124-133.

Camprubí, R. and Coromina, L. 2016. Content analysis in tourism research. Tourism Management Perspectives 18. 134-140.

CARTER, F.W. and Norris, H.T. eds. 1996. The Changing Shape of the Balkans. Boulder, Westview Press.

Cenni, I. and Goethals, P. 2017. Negative hotel reviews on TripAdvisor: A cross-linguistic analysis. Discourse, Context \& Media 16. 22-30.

Chaves, M., Gomes, R. and Pedron, C. 2012. Analysing reviews in the Web 2.0: small and medium hotels in Portugal. Tourism Management 33. 1286-1287.

Clemens, W. 2010. Ethnic peace, ethnic conflict: Complexity theory on why the Baltic is not the Balkans. Communist and Post-Communist Studies 43. 245-261.

CsászÁr, M.Zs. and PAP, N. 2011. A Balkán képzelete (Image of the Balkans). Valóság 54. (5): 40-54.

Dos SANTOS, E.R.M. 2014. Destination mutant brands: An empirical perspective of tourism professionals and host community to create Mutant Brand Cape Verde. Journal of Destination Marketing $\mathcal{E}$ Management 3. 68-78.

Ellis, M. and Wright, R. 1998. The balkanization metaphor in the analysis of U.S. immigration. Annals of the Association of American Geographers 88. (4): 686-698.

ERDősI, F. 2007. Kelet-Európa országainak légi közlekedése (Air transport in Eastern European countries). Pécs, Centre for Regional Studies, MTA.

ETC-UNWTO 2009. Handbook on Tourism Destination Branding. Madrid, ETC-UNWTO.

Galí, N., Camprubi, R. and Donaire, J.A. 2018. Analysing tourism slogans in top tourism destination. Journal of Destination Marketing \& Management 6. 243-251.

Gal-Tzur, A., Rechavi, A., Beimel, D. and Freund, S. 2018. An improved methodology for extracting information required for transport-related decisions from $Q$ \& A forums: A case study of TripAdvisor. Travel Behaviour and Society 10. 1-9.

Ganzaroli, A., De Noni, I. and van Balen, P. 2017. Vicious advice: Analysing the impact of TripAdvisor on the quality of restaurants as part of 
the cultural heritage of Venice. Tourism Management 61. 501-510.

García, J.A., Gómez, M. and Molina, A. 2012. A destination-branding model: An empirical analysis based on stakeholders. Tourism Management 33. 646-661.

GARde, P. 2007. A Balkán (The Balkans). Budapest, Háttér (Hungarian edition).

Gartner, W.C. 2014. Brand equity in a tourism destination. Place Branding and Public Diplomacy 10. 108-116.

Govers, R. and Go, F. 2009. Place Branding - Glocal, Virtual and Physical Identities, Constructed, Imagined and Experienced. New York, Palgrave Macmillan.

Grewal, R., Cline, T. and Davies, A. 2003. Earlyentrant advantage, word-of-mouth communication, brand similarity, and the consumer decisionmaking process. Journal of Consumer Psychology 13. (3): 187-197.

HajDú, Z. 2003. Az intézményes Balkán-kutatás kialakulásának és fejlődésének problémái Magyarországon 1948-ig, különös tekintettel a földrajzi kutatásokra (Issues of the formation and development of institutional Balkan studies before 1948, with particular focus on geographic studies). Pécs, Department of Nature Sciences, Geographical Institute, Centre for Eastern Mediterranean and Balkan Studies, University of Pécs.

HajDú, Z. 2007. A Balkán-félszigettől a Balkánig (From the Balkan Peninsula to the Balkans) Mediterrán és Balkán Fórum 1. (1): 10-14.

Iov, C.A. and Ivan, A.L. 2014. Identity - (In)security nexus in the EU at the end of the $20^{\text {th }}$ century and the beginning of the $21^{\text {st }}$ century. Procedia - Social and Behavioural Sciences 149. 428-432.

Jacobsen, J.K.S. and Munar, A.M. 2012. Tourist information search and destination choice in a digital age. Tourism Management Perspectives 1. January, 39-47.

JovanovićA, S., JANković-MiLićA, V. and ILIĆA, I. 2015. Health and hygiene importance for the improvement of tourism sector competitiveness in Serbia and the South-Eastern Europe countries. Procedia. Economics and Finance 19. 373-382.

Kadiu, F. 2015. Economic overview and financial instability in Balkans. Procedia. Economics and Finance 26. 1141-1145.

Kaplan, R. 1994. Balkan ghosts: A journey through history. New York, Picador.

Kavaratzis, M. and Ashworth, G. 2005. City branding: an effective assertion of identity or a transitory marketing trick? Tijdschrift voor economische en sociale geografie 96. (5): 506-514.

Kavaratzis, M., Warnaby, G. and Ashworth, G. eds. 2015. Rethinking place branding: comprehensive brand development for cities and regions. Heidelberg, Springer.
Kladou, S. and Mavragani, E. 2015. Assessing destination image: An online marketing approach and the case of TripAdvisor. Journal of Destination Marketing \& Management 4. 187-193.

Kocsis, K. ed. 2007. South Eastern Europe in Maps. Budapest, Geographical Research Institute, MTA.

Konecnik, M. and Gartner, W.C. 2007. Customerbased brand equity for a destination. Annals of Tourism Research 34. (2): 400-421.

Kôszegi, M. 2010. A magyarországi Balkán-kutatás kezdetei: korai interpretációk "a mi Keletünkről" (Beginnings of Hungarian Balkan studies: early interpretations of "our East"). X. National Convention of Geography Graduates. Szeged, University of Szeged. CD-ROM.

KozAK, M. 2010. Holiday taking decisions - the role of spouses. Tourism Management 31. 489-494.

Kozma, G. 1995. A debreceni önkormányzat első lépései a városmarketing területén (The first steps of the Debrecen local government in city marketing). Comitatus 5. (5): 15-21.

Kozma, G. and Ashworth, G. 1993. Projected urban images: A comparison of Groningen and Debrecen. Groningen Studies 55. 1-32.

KumaR, V. and NAJAK, J.K. 2014. The measurement \& conceptualization of destination personality. Tourism Management Perspectives 12. 88-93.

Ladhari, R. and Michaud, M. 2015. eWOM effects on hotel booking intentions, attitudes, trust and website perceptions. International Journal of Hospitality Management 46. April, 36-45.

LaitamëKI, J.M. and HämäLÄInen, T.J. 2008. Drivers of Globalization in the Tourism Industry: Global Strategies for Country Destination Brands. Conference paper. Competition in Tourism: Business and Destination Perspectives Conference, TTRA Europe Chapter, Helsinki, Finland, 23-25 April, 2008.

Lee, G., CaI, L.A. and O'Leary, J.T. 2006. WWW. Branding.States.US: An analysis of brand-building elements in the US state tourism websites. Tourism Management 27. 815-828.

LeE, J.S. and BACK, K.J. 2010. Reexamination of attendee-based brand equity. Tourism Management 31. 395-401.

Luo, Q. and ZHong, D. 2015. Using social network analysis to explain communication characteristics of travel-related electronic word-of-mouth on social networking sites. Tourism Management 46. February, 274-282.

Malenkina, N. and Ivanov, S. 2018. A linguistic analysis of the official tourism websites of the seventeen Spanish Autonomous Communities. Journal of Destination Marketing \& Management https://doi. org/10.1016/j.jdmm.2018.01.007

Marine-Roig, E. and Anton Clavé, S. 2015. Tourism analytics with massive user-generated content: 
A case study of Barcelona. Journal of Destination Marketing \& Management 4. 162-172.

Martin, W. and Lueg, J. 2013. Modelling word-ofmouth usage. Journal of Business Research 66. (7): 801-808.

Marzano, G. and Scott, N. 2009. Power in destination branding. Annals of Tourism Research 36. (2): 247-267.

Matanov, A., Giacco, D., Bogic, M., Ajdukovic, D., Franciskovic, T., Galeazzi, G.M., Kucukalic, A., Lecic-Tosevski, D., Morina, N., Popovski, M., Sснüтzwohl, M. and Priebe, S. 2013. Subjective quality of life in war-affected populations. BMC Public Health 13:624. https://doi.org/10.1186/14712458-13-624

Mauri, A. and Minazzi, R. 2013. Web reviews influence on expectations and purchasing intentions of hotel potential customers. International Journal of Hospitality Management 34. September, 99-107.

Moilanen, T. and Rainisto, S. 2009. How to Brand Nations, Cities and Destinations - A Planning Book for Place Branding. New York, Palgrave Macmillan.

Munar, A.M. and Jacobsen, J.K.S. 2014. Motivations for sharing tourism experiences through social media. Tourism Management 43. August, 46-54.

NAGY, M. 2012. Balkán-kép vagy a Balkán képei? A Balkán-félsziget a magyar katonai utazási irodalomban (Balkans image or images of the Balkans? The Balkan Peninsula in Hungarian military travel literature). Közép-Európai Közlemények 5. (1): 15-27.

NAM, J., EkINCI, Y. and WhyATt, G. 2011. Brand equity, brand loyalty and consumer satisfaction. Annals of Tourism Research 38. (3): 1009-1030.

Newman, B. 1945. Balkan background. New York, Macmillan.

O'Brennan, J. 2014. “On the Slow Train to Nowhere?" The European Union, "Enlargement Fatigue" and the Western Balkans. European Foreign Affairs Review 19. (2): 221-242.

Он, H. 1999. Service quality, customer satisfaction, and customer value: a holistic perspective. Hospitality Management 18. (1): 67-82.

Palmer, A., Koenig-Lewis, N. and Medi Jones, L.E. 2013. The effects of residents' social identity and involvement on their advocacy of incoming tourism. Tourism Management 38. 142-151.

PAP, N. 2013. Hungary, the Balkans and the Mediterranean. Pécs, Publikon Kiadó.

Papp-VÁry, A. 2013. A márkanév ereje. Szempontok a sikeres brandépitéshez (Power of a brand name. Considerations for a successful branding). Budapest-Pécs, Dialóg Campus Kiadó.

Petrovic, M. 2008. The role of geography and history in determining the slower progress of postcommunist transition in the Balkans. Communist and Post-Communist Studies 41. (2): 123-145.
PIKE, S. 2002. Destination image analysis - a review of 142 papers from 173 to 2000. Tourism Management 23. 541-549.

PIKE, S. 2009. Destination brand positions of a competitive set of near-home destination. Tourism Management 30. 857-866.

PIKE, S. and PAGE, S. 2014. Destination marketing organizations and destination marketing: A narrative analysis of the literature. Tourism Management 41. 202-227.

Qu, H., Кıм, H. and Iм, H. 2011. A model of destination branding: integrating the concepts of the branding and destination image. Tourism Management 32. 465-476.

Raguseo, E., Neirotti, P. and Paolucci, E. 2017. How small hotels can drive value their way in infomediation. The case of 'Italian hotels' vs. OTAs and TripAdvisor. Information Management 54. 745-756.

RÁTz, T. 2006. Kulturális turizmus és városfejlesztés: Európa Kulturális Fővárosa" (Cultural tourism and urban development: European Cultural Capital). Turizmus Bulletin 10. (2): 9-15.

Redepenning, M. 2002. Was und wie ist der Balkan? Geographische Rundschau 54. (7): 10-15.

Rodrigues, H., Troilo, M., Brochado, A. and Mohsin, A. 2017. Mirror, mirror on the wall, who's the fairest of them all? A critical content analysis on medical tourism. Tourism Management Perspectives 24. 16-25.

RUtAR, S. 2004. Beyond the powder keg? Representations of the former Yugoslav countries in Italian history textbooks of the 1990s. Journal of Southern Europe and the Balkans Online 6. (2): 183-204.

SAnguin, A. 2011. Montenegro in Rebecca West's Black lamb and grey falcon: the literature of travellers as a source for political geography. Geoadria 16. (2): 253-260.

Saraniemi, S. 2010. Destination brand identity development and value system. Tourism Review 65 . (2): 52-60.

Seben, G. 2007. A Balkán nyomában: a Balkán szociális reprezentációja Magyarországon, pécsi egyetemi hallgatók körében végzett vizsgálat alapján (Following the Balkans: social representation of the Balkans in Hungary, based on a study among students of the University of Pécs). Mediterrán és Balkán Fórum 1. (2): 16-19.

SzÉKELy, A. 1970. Az ezerarcú Balkán-félsziget (A thousand faces of the Balkan Peninsula). In Európa 1. Eds.: Marosi, S. and Sárfalvi, B., Budapest, Gondolat Kiadó, 248-278.

TAmminen, T. 2004. Cross-border cooperation in the Southern Balkans: local, national or European identity politics? Southeast European and Black Sea Studies 4. (3): 399-418.

Tasci, A.D.A., Gartner, W.C. and Cavusgil, S.T. 2007. Measurement of destination brand bias using a quasi-experimental design. Tourism Management 28. 1529-1540. 
Thanh, T.V. and Kirova, V. 2018. Wine tourism experience: A netnography study. Journal of Business Research 83. 30-37.

Torres, E., Adler, H. and Behnke, C. 2014. Stars, diamonds, and other shiny things: the use of expert and consumer feedback in the hotel industry. Journal of Hospitality and Tourism Management 21. September, 34-43.

Usakli, A. and Baloglu, S. 2011. Brand personality of tourist destinations: An application of selfcongruity theory. Tourism Management 32. 114-127.

Vermeulen, I. and Seegers, D. 2009. Tried and tested: the impact of online hotel reviews on consumer consideration. Tourism Management 30. (1): 123-127.
Vitic, A. and Ringer, G. 2008. Branding post conflict destinations. Journal of Travel and Tourism Marketing 23. (2-4): 127-137.

WANG, S. and $\mathrm{XU}_{\mathrm{U}}, \mathrm{H}$. 2015. Influence of place-based senses of distinctiveness, continuity, self-esteem and self-efficacy on residents' attitudes toward tourism. Tourism Management 47. 241-250.

WTO 2002. Shining in the Media Spotlight - A Communication Manual for Tourism Professionals. Madrid, World Tourism Organization. 